\title{
Impact of Socio Economic Factors on Women Work force Participation in Informal Sector of Assam
}

\author{
Krishna Saikia
}

\begin{abstract}
Informal sector has played a very important role in the labour market of most of the development countries like India. Informal employment has been widespread and continues to be an emerging phenomenon. An overwhelmingly large percentage of workers (about 92 per cent) are engaged in informal informal sector of India and a large majority of them have low earnings with limited or no social protection. Assam is one of the relatively backward states in India. In Assam, the labour force participation rate (LFPR) and work force participation rate (WFPR) shows a dark picture of the labour market of the state. As similar to National level, in this state also, more than $90 \%$ of total workforce is engaged in informal sector. Informal sector provides a better scope for women to engage in various activities like small tea shop, street vendor, beauty parlour, rag picker etc. Generally, women in the informal sector in India are disadvantaged in the field of labour market. Their low productivity, low income, insecure jobs, as well as low share in overall employment in the unorganised and informal sectors shows a gloomy picture The inequalities and disparities that exist in access to employment across regions and social groups remain a huge competition in India. In this study an attempt is made to analyze the issues and challenges faced by the women informal workers in different sectors in Assam.
\end{abstract}

Keywords : Size of the Informal Workers, Types of Informal Workers, Problems of Informal Sector Workers

\section{INTRODUCTION}

Informal sector has played a very important role in the labour market of most of the development countries like India. Informal employment has been widespread and continues to be an emerging phenomenon. An overwhelmingly large percentage of workers (about 92 per cent) are engaged in informal informal sector of India and a large majority of them have low earnings with limited or no social protection. Assam is one of the relatively backward states in India. In Assam, the labour force participation rate (LFPR) and work force participation rate (WFPR) shows a dark picture of the labour market of the state. As similar to National level, in this state also, more than $90 \%$ of total workforce is engaged in informal sector. The informal sector involves different types of activities and workers including agricultural workers, home-based workers, labour on construction sites, domestic worker, handicrafts, khadi etc. Informal sector provides a better scope for women to engage in various activities like small tea shop, street vendor, beauty parlour, rag picker etc. Generally, women in the informal sector in India are disadvantaged in the field of labour market. Their low productivity, low income, insecure jobs, as well as low share in overall employment in the unorganised and informal sectors shows a gloomy picture (Banerjee \& De 2018). The unequal access of women to employment and discrimination in the labour market, poses yet another challenge. The inequalities and disparities that exist in access to employment across regions and social groups remain a huge competition in India. In this study an attempt is made to analyze the issues and challenges faced by the women informal workers in different sectors in Assam.

\section{REVIEW OF LITERATURE}

\section{A. Informal Sector:}

Keith Hart was the first person who used the term 'Informal Sector' in his study of urban Ghana in 1971. He described the informal sector as that part of the urban labour workforce which falls outside the extent of the formal/formal labour market. This concept of informal sector has been redefined by the International Labour of Organizations' (ILO) Kenya Mission Reports of 1972.

ILO (1991) defined Informality as a way of doing things characterised by- "(a) Ease of entry, (b) Reliance of indigenous resources (c) Family ownership (d) Small scale operations (e) Labour intensive and adaptive technology (f) Skills acquired outside of the formal sector (g) Unregulated and competitive market."

Mazumdar (1975) defined makes a distinction between formal and informal sectors and terms the informal sector as unproductive sector because it does not enjoy any social security benefits, nor is it protected by the government or trade unions or both.

According to Joshi and Joshi (1976), the formal and informal sector can be separated on the basis of three main factors i.e. market structure, technology and its relationship with the government

\section{B. National Perspective:}

According to the National Commission for Enterprises in the Informal Sector (NCEUS) "Informal workers consists of those working in the informal sector or households, excluding regular workers with social security benefits provided by the employers and the workers in the formal sector without any employment and social security benefits provided by the employers" 


\section{Literature on the various Socio-economic factors that lead to higher participation of women in the Informal sector.}

There are several studies on female labours in the Informal sector with different types of activities in most of the development countries like India. There are various factors that lead to the women participation in several economic activities in order to improve their health condition as well as living condition of their family.

Earning income is another important cause of joining women in the unorganized sector jobs. Through these jobs they have earned adequate amount of money and improve their living standard. In his study, it is observed that the women worker belongs to informal sector contributed roughly about $45 \%$ of the income of his family. Another researcher (Tripathy and Das 1991) found in his study that majority of women workers engaged in informal sector in West Bengle contributed a larger proportion of income to the family. According to the (Swami and others 1989) women go to work because of their husband was involved in irregular nature of employment and work and which lead to very low monthly income they make Poverty is one of the important cause to join women worker in the Informal sector. (Saheb, 2011) focused on the poverty of unregistered female and informal sector workers. He found disparate proportion of workers which were below poverty line i.e., in Puri 37\%, in Agra 51\% and in Kanpur $47 \%$ were below poverty line. Most of the workers in these cities belonged to below poverty line because of their fathers' indebtedness.

Illiteracy as well as low level of education is another important factor that compel women to engaged in the Informal sector. Researcher Evenzer Ravichandran (1988), in his studies in slums areas of Maharastra observed that almost $50 \%$ of women labours were illiterate, $40 \%$ had acquired education up to primary level, and only $10 \%$ had acquired education up to secondary level. So they are not eligible to get job in the organized and formal sector.Again Tripathy and Das (1991) found that there are various problems faced by the women informal labour of Orissa district. His field survey found that majority of women did not have any formal education as well as formal vocational training. So they have to engaged in the Informal sector jobs.

\section{Literature on problem faced by the women workers of Informal sector in India and Assam:}

Low wages accompanied by long hours of work is a characteristic of the informal sectors in most of the developing countries like India. Generally, the long working hours is a severe problem on the social and family life of labourers, especially for women labourers in particular. They do not find any time to take part in cultural or social activities as well as to take proper child care. Mohapatra, (2012) explained the problem of female workers employed in informal sector. They found that women workers are facing the problems of exploitation, low wages, and long working hours. They were struggling with many problems fraud, menacing, assault. Majumder (1975) in his research paper on working condition of women workers in Maharashtra identify the temporary nature of job, long working hours, absence of leave facilities, lack of opportunity for promotion, low wages and deprivation from minimum wage and gender discrimination as unique features of the sector. The wage discrimination on the basis of sex is examined by Shing (1999). He found in Uttar Pradesh that social prejudices and family compulsion are main reason for wage differentials on the basis of sex. He also found that women earnings were very less as compared to men.

Jaishankar \& Sujatha,(2016) found their survey in Tiruchirappallicty about hygienic practices among food vendors. Generally the food vendors were quite aware of hygienic conditions. But the majority of the street vendors were not executing their knowledge into practice. They become aware of that their products were little risk to the customers. It focuses attention on the need for further health education of street food vendor

Ahmed \& Ahmed, (2017) their study of Maharastra city found that workers in the informal sector enterprises, irrespective of which state they belong to, do not secure any documented job-contact, paid leaves and other social security benefits. She observed that illiteracy and the lack of training increase the risk of getting insecured jobs. This job insecurity implies income insecurity. Srivasta, (2010) found his study of Chennai that the informal sector workers often undertake multiple jobs, and call this a sign of job insecurity. These workers in the informal economy are exposed to various forms of risk that could be structural or random shocks.

\section{OBJECTIVES: -}

1. To examine the size of women informal workers of Assam.

2. To examine the main factors that lead to higher participation of women in the Informal sector.

\section{DATA SOURCE AND METHODOLOGY: -}

The study is based on secondary data. Secondary data have been collected both at the state and national level. The secondary data have been collected from National Sample Survey Organisation (NSSO), Assam State Disaster Management Authority, Directorate of Economics and Statistics (Assam), various journal, magazines, Ph.D. thesis etc.

\section{RESULT AND ANALYSIS:}

\section{A. Size and Trend of Informal Sector Workers in India and Assam:}

In India, NSSO provides extensive data base on the field of informal sector. In the NSSO survey, employment is defined in four distinct measures i.e. - Current Daily Status (CDS), Current Weekly Status (CWS), Usual Principal Status (UPS), and Usual Principal and Subsidiary Status (UPSS). NSSO has also categorized the workers as regular, self-employed and casual. Aside from this, students, pensioner, homework etc. are categorized as non-worker (NSSO 61st Round).

From various review of literature, we notice two procedures to calculate the informal sector employment in India. The two methods are - (a) residual method and (b) Direct method. 


\section{B. Estimates of Informal Sector Workers in India and Assam since 1999-2000 to 2011-12:}

Informal sector plays a dominant role in the Indian labour market since employment in the formal sector has been remain more or less stagnant in the last decades and employment opportunities in the informal sector has been tremendous, Sakthival \& Joddar (2006).

\section{Table- I}

Size of Formal-Informal Sector Worker in India since 1999-2000 to 2011-12 (million)

\begin{tabular}{|c|c|c|c|c|c|}
\hline Year- & $\begin{array}{c}\text { Formal } \\
\text { (million) }\end{array}$ & $\begin{array}{c}\text { Inform } \\
\text { al } \\
\text { (millio } \\
\mathrm{n})\end{array}$ & $\begin{array}{c}\text { All } \\
\text { (million) }\end{array}$ & $\begin{array}{c}\text { Formal } \\
\text { (Percen } \\
\text { tage) }\end{array}$ & $\begin{array}{c}\text { Inform } \\
\text { al } \\
\text { (Percen } \\
\text { tage) }\end{array}$ \\
\hline $\begin{array}{c}1999-20 \\
00\end{array}$ & 27.84 & 370.05 & 397.89 & 7.00 & 93.00 \\
\hline $2004-05$ & 26.46 & 431.02 & 457.48 & 5.78 & 94.22 \\
\hline $2009-10$ & 28.29 & 436.98 & 465.27 & 6.08 & 93.92 \\
\hline $2011-12$ & 26.53 & 446.37 & 472.9 & 5.61 & 94.67 \\
\hline
\end{tabular}

Source: NSSO various rounds 55th, 61st, 66th and $68^{\text {th }}$ round

Both formal and informal employment trend has been shown in table 1 for the years 1999-2000, 2004-05, 2008-09, and 2011-12. It is observed that throughout this period a huge percentage of the labour force is found to be engaged in informal sector of India. Out of 472.9 million workers in 2011-12, it is computed that 446.37 million workers (around $95 \%$ ) are engaged in informal sector whereas 26.53 million (nearly 5\%) workers are employed in formal sector. Apart from this, the total employment in informal sector is raised from 370 million to 446 million between 1999 - 2000 and 2011- 12 where labour force is raised by almost 76 million or which is nearly 21 percent. The percentage of informal sector employment has risen from 93 percent in 1999-2000 to 94 percent in 2004-05, 93.92 percent in 2009-10 and again increasing to 94.67 percent in 2011-12. It is observed that the percentage of employment opportunities in the formal sector have remained stagnant during the period of 1999-2000 to 2011-12, only a marginal decreasing from 27.84 to 26.53 million.

Table- II

Percentage of Formal and Informal Sector Workers in Total Employment of India

\begin{tabular}{|c|c|c|c|c|c|c|}
\hline Year & \multicolumn{2}{|c|}{ Male Worker (Percent) } & \multicolumn{2}{c|}{$\begin{array}{c}\text { Female Worker } \\
\text { (Percent) }\end{array}$} & \multicolumn{2}{c|}{ Persons (Male + Female) (Percent) } \\
\hline & Formal & Informal & Formal & Informal & Formal & Informal \\
\hline $1999-00$ & 8.35 & 91.65 & 4.00 & 96.00 & 7.00 & 93.00 \\
\hline $2004-05$ & 6.94 & 93.06 & 3.37 & 96.63 & 5.78 & 93.92 \\
\hline $2009-10$ & 6.68 & 93.32 & 4.51 & 95.49 & 6.08 & 94.29 \\
\hline $2011-12$ & 5.74 & 94.26 & 4.81 & 95.19 & 5.71 & \\
\hline
\end{tabular}

Source: NSSO various rounds

The trend of the formal sector workers has remained more or less stable during this period (Table 2). Approximately, $90 \%$ of workers both men and women had been working in the informal sector among the three NSSO round of 1999-2000, 2004-05, 2009-10 and 2011-12. The group of male workforce and total male and female workforce (person), the proportion of informal sector workforce has been indicating a growing trend from $91.65 \%$ to $93.06 \%$ and $93.32 \%$ to $94.26 \%$ during the period of $1999-2000$ and 2011-2012 respectively. In case of female worker, the rate of percentage had been rising from $96 \%$ in 1999-2000 to $96.63 \%$ in 2004-05, again slightly decreasing to 95.49 percent in 2009-10 and 95.19 percent in 2011-12.

\section{Estimates of Informal sectors workers in Assam during 1999-2000 to 2011-12:}

Table: - 3 Percentage of Informal sectors workers in Assam during 1999-2000 to 2011-12

\begin{tabular}{|c|c|c|c|c|c|c|}
\hline \multirow{2}{*}{ Year } & \multicolumn{2}{|c|}{ Male Worker } & (Percent) & \multicolumn{2}{c|}{$\begin{array}{c}\text { Female Worker } \\
\text { (Percent) }\end{array}$} & \multicolumn{2}{|c|}{$\begin{array}{c}\text { Persons (Male + Female) } \\
\text { (Percent) }\end{array}$} \\
\cline { 2 - 6 } & $\begin{array}{c}\text { Formal } \\
\text { labour }\end{array}$ & $\begin{array}{c}\text { Informal } \\
\text { labour }\end{array}$ & $\begin{array}{c}\text { Formal } \\
\text { labour }\end{array}$ & $\begin{array}{c}\text { Informal } \\
\text { labour }\end{array}$ & $\begin{array}{c}\text { Formal } \\
\text { labour }\end{array}$ & $\begin{array}{c}\text { Informal } \\
\text { labour }\end{array}$ \\
\hline
\end{tabular}




\begin{tabular}{|c|c|c|c|c|c|c|}
\hline $1999-00$ & 10.24 & 89.76 & 18.77 & 81.23 & 12.00 & 88.00 \\
\hline $2004-05$ & 9.29 & 90.71 & 13.66 & 86.34 & 10.39 & 89.61 \\
\hline $2009-10$ & 8.63 & 91.37 & 16.41 & 85.59 & 10.23 & 89.77 \\
\hline $2011-12$ & 8.59 & 92.40 & 15.49 & 84.50 & 10.07 & 90.22 \\
\hline
\end{tabular}

Source: NSSO various rounds

Table: 3 , it is noticed that almost $88 \%$ of the total workers of Assam was working in informal sector in 1999-2000, whereas 12 percentages was engaged in formal sector. Approximately, $90 \%$ of the total workers both male and female had been working in informal sector among the three NSSO round of 2004-05, 2009-10 and 2011-12. The group of male workforce as well as total male and female workforce (person), (Table 4.4) the percentage of informal sector workforce has been displaying a upward trend from $89.76 \%$ to $92.40 \%$ and $88 \%$ to $90.22 \%$ during the period of 1999-2000 and 2011-2012 respectively. In case of female worker, the rate of percentage was growing from almost $81 \%$ in $1999-2000$ to $86 \%$ in 2004-05, again slightly decreasing to 84.50 percent in 2011-12.

\section{To examine the main factors that lead to higher participation of women in the Informal sector of Assam: -}

Researchers have found that women workforce participation in the informal labour market depending on different types of factors or determinants rather than salary as well as wage rate. The main determinants include number of children, size of the family, type of family, age, distance of the workplace from home etc. The theoretical as well as conceptual background of women workers in the present study is trying to investigate the various factors

which influenced the total supply of women workforce ithe informal labour market such as percentage of Informal women workforce in the house holds (Y) considered as a explained variable or dependent variable.

There are a few number of independent or explanatory variables like total number of children which is under the age of 6 years $(\mathrm{C})$, percentage of male workforce between the age group of 15-65 years (M), percentage of female workforce between the age group of 15-65 years out of total number of women in the age group $(\mathrm{F})$, total number of women with below primary level of education (E), monthly wise income of the household $(\mathrm{H})$ and agricultural land holding of household (A).

\begin{tabular}{|c|c|}
\hline Dependent Variable & Independent Variable \\
\hline $\begin{array}{l}\text { - Percentage of women workforce in the } \\
\text { (informal sector) households }=\mathrm{Y}\end{array}$ & $\begin{array}{l}\text { - Total number of children which is under the age of } 6 \\
\text { years (C), } \\
\text { - Percentage of male workforce between the age group of } \\
\text { 15-65 years (M), } \\
\text { - Percentage of female workforce between the age group } \\
\text { of } 15-65 \text { years out of total number of women in the age } \\
\text { group (F), } \\
\text { - Total number of women with below primary level of } \\
\text { education (E), } \\
\text { - Monthly wise income of the household (H) and } \\
\text { - Total number of agricultural land holding of household } \\
\text { (A). }\end{array}$ \\
\hline
\end{tabular}

\section{- Model Formation:-}

We have $\mathrm{Y}=\mathrm{F}(\mathrm{M}, \mathrm{C}, \mathrm{F}, \mathrm{E}, \mathrm{H}, \mathrm{A})$ i.e value of $\mathrm{Y}$ assumed to be dependent variable $\mathrm{M}, \mathrm{C}, \mathrm{F}, \mathrm{E}, \mathrm{H}, \mathrm{A}$, assumed to be independent variable.

\section{- Linear Model:-}

The linear function of the model becomes as Or $\quad \mathbf{Y}=\alpha+\boldsymbol{\beta M}+\boldsymbol{\mu C}+\boldsymbol{\delta} \mathbf{F}+\lambda \mathbf{E}+\mathbf{\epsilon H}+\mathbf{\$ A}+\mathbf{U}$ Where, $\mathrm{U}$ is error term 
Table- IV

Description of the Variable or Expected signs of Co-efficient

\begin{tabular}{|c|c|c|c|c|c|c|}
\hline $\begin{array}{r}\text { Sl } \\
\text { No }\end{array}$ & Explanatory Variables Name & Coefficient & S.E. & t-value & Sig. & p-value \\
\hline 1 & Constant (Intercept term) & 1.514 & 0.159 & 7.779 & 0.000 & - \\
\hline 2 & $\begin{array}{c}\text { M (Percentage of male } \\
\text { workforce between the age } \\
\text { group of } 15-65 \text { years) }\end{array}$ & 0.140 & 0.085 & 1.251 & 0.119 & 0.11 \\
\hline 3 & $\begin{array}{c}\text { Percentage of female workforce } \\
\text { between the age group of } 15-65 \\
\text { years }\end{array}$ & -0.488 & 0.074 & -3.503 & 0.024 & -0.216 \\
\hline 4 & $\begin{array}{c}\mathrm{H} \text { (Monthly wise income of the } \\
\text { household }(\mathrm{H})\end{array}$ & 0.036 & 0.014 & 2.251 & 0.018 & 0.001 \\
\hline 5 & $\begin{array}{c}\text { E (Below primary level of } \\
\text { education )of Informal female } \\
\text { workers }\end{array}$ & 0.248 & 0.078 & 3.003 & 0.002 & 0.069 \\
\hline 6 & $\begin{array}{l}\text { Ag (Agricultural } \\
\text { landholdings of the households) }\end{array}$ & 0.010 & 0.041 & 0.238 & 0.805 & 0.001 \\
\hline 7 & $\begin{array}{c}\mathrm{C} \text { (Total number of children } \\
\text { which is under the age of } 6 \text { years }\end{array}$ & -0.178 & 0.087 & -2.064 & 0.031 & -0.124 \\
\hline 8 & Y (Dependent Variable) & \multirow{2}{*}{\multicolumn{2}{|c|}{ Adjusted $\mathrm{R}^{2}=0.201$}} & & & 1.000 \\
\hline 9 & $\mathrm{R}^{2}=0.233$ & & & \multicolumn{2}{|c|}{$F=7.664$} & Sig $=0.000$ \\
\hline
\end{tabular}

\section{- Interpretation of the model-}

In case of linear model we assume that there is a constant linear relationship between percentage of Informal women workers and all the variables such as number of children, proportion of male workers, proportion of female workers, total number of women labour who's education is below primary level, monthly wise household income and total agricultural land of the household. But the result of regression analysis gives certain different results as against our assuming. So this can be giving a brief interpretation of the result of regression.

In the table 4 we can see that $\mathrm{F}=7.664$ and a linear fit with $\mathrm{R}^{2}=0.233$. This means that $23.3 \%$ of the variance has been accounted for in our model. Table no 4 we can observe that the total number of male workers in household with $(p=0.11)$ has a low significant relationship with the dependent variable proportion of Informal women workers at 5\% level of significance.

On the other hand, the variable household income $(\mathrm{p}=0.001)$ has highly significant relationship with the dependent variable proportion of Informal women workers at 5\% level of significance.

The variable of female workforce between the age group of $15-65$ years has negative sign of $p$ value $(p=-0.216)$ which implies that there is a negative impact of independent variable on the dependent variable of percentage of Informal women workers.

Apart from this, the total number of women labour who's education is below primary level is statistically significant in the regression model with $(\mathrm{p}=0.069)$, indicate there is a positive impact on the dependent variable of proportion of Informal women workers.

Another variable total number of agricultural land of the household is highly significant in this model with $\mathrm{p}$ value is (0.001) has a strong relationship with the dependent variable proportion of Informal women workers at 5\% level of significance.
Total number of children which is under the age of 6 years has has negative sign of $p$ value $(p=-0.124)$ which implies that there is a negative impact of independent variable on the dependent variable of percentage of Informal women workers. The regression result shows that "Children below six years of age' is significant in the model. The coefficient of the variable 'number of children below six years of age' has negative sign which indicate negative association between the two variables. As the number of children below six years of age in the household increases the supply of Informal women workers decreases. That is, the presence of young children affects women's labour supply negatively. This result indicates that sexual division of labour is visible in the study area which held the view that women's primary role is reproduction-the bearing and caring of children.

\section{FINDINGS OF THE STUDY}

- Informal sector has a vast scope of employment opportunity in India as well Assam; almost 95 percent of workers in India and about 90 percent of the total workers are engaged in informal sector of Assam.

- As compared to the state level of Assam, in India, the percentage of informal employment is much higher because the informal sector is quite visible in various sectors of the Indian economy as compared to the Assam for e.g. household, industry, agriculture as well as service sectors.

- Comparison between Assam and national level, regarding the share of informal sector workers tells that the percentages of informal sector workers are higher in all categories at national level than Assam. It has been seen that formal sector employment of Assam is slightly higher than the national level. Approximately, 10 percent and 5.61 percent of the workers are engaged in formal sector

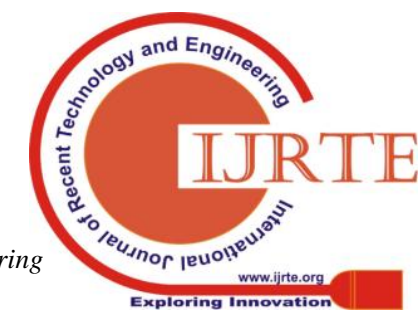


of Assam and National level respectively.

- There are several factors that leading to higher participation of women in the Informal sector number of alive children, their age, type of family, education, size of the family, health of family members, nature and type of the job, distance of the workplace, etc.

- The independent variable below primary level of education of Informal female workers is statistically significant in the regression model with $(\mathrm{p}=0.06)$

- The independent variable household income is significant in the model. The two variables have positive correlation $(\mathrm{p}=0.001)$ in the model.

- Another variable agricultural land holdings of the household is highly significant in this model with $\mathrm{p}$ value is (0.001) has a strong relationship with the dependent variable proportion of Informal women workers at $5 \%$ level of significance.

\section{CONCLUSION}

From the above discussion it is evident that rather than being absorbed into modern formal wage employment, Indian labour force is becoming increasingly informal. Changes in employment pattern may reflect the intense competition, risk and uncertainty, which both the employers and employees face due to globalisation. Not only in India, this type of trend prevalent in the state of Assam also. NSSO data reveals that though female workforce participation rate in India as well as Assam has increased, most of the employment was informal in nature. This predominance of informality may be attributed to lower bargaining power, immobility and higher rate of illiteracy of female population. Though, general idea is informality indicates lower job quality, we may conclude with the view that it is better to be employed, even if it is informal in nature, rather than being unemployed. In case of India decreased rate of unemployment is due to rise in informal employment including self-employment. Such employment enhances the purchasing power among the poorer (both urban and rural) cross section of the society, which turns out to be beneficial for the overall long run development of the economy. Keeping this in mind, Government of India has taken several initiatives like MGNREGS or Micro Finance programme, in order to create employment or enhance self-employment activities among the rural as well as urban labour force. These employments are informal in nature, but have huge impact on livelihood of rural and urban population. Therefore, the study suggests that policy should be taken in order to create ambiance which will facilitate small and micro enterprises.

\section{REFERENCES}

1. U Chakravarty and N.A Baruah, (2008): "Employment Generation in Urban Informal Sector: A Case Study of Guwahati City, Urban India", National Institute of Urban Affairs, New-Delhi, Vol. xxviii, No $1 \&$ 2, pp163-175.

2. J D P Choudhury, (2003): “Women Workers in Informal Sectors and Their Qualitative Contribution in Human Capital: A Micro Study on Greater Guwahati", PhD thesis, Guwahati University, Assam.

3. D Das (2014): "Women Labour in the Unorganized sector: A Study in Palashbari Revenue Circle of Kamrup District, Assam", PhD Thesis, Gauhati University, Assam.

4. N Das (2016): "Employment Generation of the Urban Informal Sector of Assam: A Case Study of Guwahati City", PhD Thesis, Gauhati University, Assam.
5. R Geetha (2014): "Disparities in earnings and education in India", Cogent Economics \& Finance, accessed from http://dx.doi.org/10.1080/23322039.2014.941510.

6. Government of India (2012): "Report of the Committee on Unorganised Sector Statistics", National Statistical Commission.

7. C Gowthaman (2017): "Socio-economic Status of Brick Workers in Namakkal District", Imperial Journal of Interdisciplinary Research, Vol. 3, No 10

8. K Hart (1973): "Informal Income Opportunities and Urban Employment in Ghana," Journal of Modern African Studies, (London), March, pp 61-89.

9. ILO (1972): “Employment, Incomes and Equality: A Strategy for increasing Productive Employment in Kenya", Employment, Geneva.

10. ILO (1991): "Employability in the global economy-How training matters", World Employment Report, pp 173.

11. ILO (2002): "Women and Men in the Informal Economy: A Statistical Picture," Geneva.

12. R Jhabwala and U Jumani, (1988): “Ahmedabad 2001: Planning for the Poor-A Focus on Self-Employed Women", Nagarlok, Vol 20, No 4, pp76-96.

13. K P Kannan (2012): "How Inclusive is Inclusive Growth in India", Working Paper WP03/2012, New Delhi: Institute for Human Development (IHD).

14. J Kanungo (1991),"The Young Girls Helping us in our Household Work", in Patil, R.N. (Ed) "Rehabilitation of Child Labourers in India", A thesis Publishing House, N. Delhi.

15. K Majumdar (1981),“Employment Generation of the Urban Informal Sector" EPW, Vol 6, No 4, pp 44-78

16. NCEUS (2009): “The Challenge of Employment in India: An Informal Economy Perspective", New Delhi.

17. NSSO (2001): "Employment-Unemployment Situation in India 1999-2000", Round 55th Report No-458, I and II (55/10/2), MOSPI, Government of India, New-Delhi.

18. NSSO (2006): "Employment -Unemployment Situation in India 2004-2005", Round 61st, Report No-515, I and II (61/10/1 \&2), MOSPI, Government of India, New Delhi.

19. NSSO (2011): "Employment -Unemployment Situation in India 2009-2010”, Round 66st, Report No-537, (66/10/1 \&2), MOSPI, Government of India, New Delhi.

20. NSSO (2012): "Informal Sector and Conditions of Employment in India 2009-2010", Round 66st, Report No-539, (66/10/2), MOSPI, Government of India, New Delhi.

21. NSSO (2013): “Employment -Unemployment Situation in India 2011-2012", Round 68st, Report No-537, (66/10/1 \&2), MOSPI, Government of India, New Delhi.

22. E Ravichndran, (1987), "A Study of the Socio-Economic Conditions of Women Domestic Workers Residing in South Pudur Slum", Research Report(unpublished) Layala Institute of Development Sciences, Madras

23. N P Sharma (1989), "Wage Differential for Women Agricultural Labourers', Yojana, July.

24. M P Todaro (1969): “A Model of Labor Migration and Urban Unemployment in Less Developed Countries", American Economic Review, Vol. 59, pp. 138-48.

25. V P Tokman (1992): "The informal sector in Latin America - From underground to legality", in Tokman, V E (Ed.) Beyond Regulation: The Informal Economy in Latin America, Lynne Rienner publishers.

26. J Unni (2005): "Wages and Incomes in Formal and Informal Sectors in India", The Indian Journal of Labour Economics, Vol. 48, No 2.

27. V Upadhyay (2007): "Employment and earnings in urban informal sector - A study on Arunachal Pradesh", NLI, V. V. Giri, NOIDA

\section{AUTHORS PROFILE}

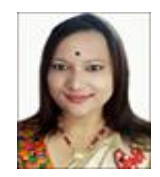

Krishna Saikia,

Research Scholar, Department of Economics, Gauhati University.

Email id- saikiakrishna373@gmail.com 